\title{
Further promoting the reform of property tax in China
}

\author{
Mengting Long \\ School of Economic and Management, North China Electric Power University, Beijing, 102206 \\ China
}

13264421172@163.com.

\begin{abstract}
Property taxes can help to raise revenue, optimize the allocation of resources and adjust income distribution. It is one of the national macro-control means in real estate development industry, which has great economic and social benefits. However, due to its design flaws and insufficient tax collection system, China's current property tax system cannot play a very good adjustment to raise financial income and distribution. By analyzing the shortcomings of the existing property tax system, some suggestions of property tax reform are to be put forward to further promote the reform of property tax, combined with the advanced experience of the American and Japanese property tax reform.
\end{abstract}

Keywords: Reform In Property Tax; Obstacles In Promotion; Experience Of America and Japan; Measures In Promoting.

\section{Introduction}

Our Property Tax Reform officially began in Shanghai and Chongqing in January 2012. It is aimed to curb investment, speculative demand, increase the local government financial income and regulate the distribution of income. However, the actual operation of the process has suffered some challenges. To further promote the reform of property tax, some researches are carried out.

After researching, two main problems are found out [1, 2]. One problem is the tax system design flaws, including that the legal status of the property tax system is low, the scope of taxation is narrow and the tax rate is single. The other one is that the collection and management system are not perfect, which means that we lack relevant collection mechanism of property tax and relevant tax valuation organizations.

Contrasting with the experience of the US and Japan in property tax reform, the property tax reform for China can be proposed to promote property tax reform in depth.

\section{The property tax reform in the United States and Japan}

Nowadays, many countries and regions have imposed property taxes on the property, which is known as property tax in the United States and real estate tax in Japan. The United States is now the most developed countries whose property tax system is unique, while Japan is Asia's developed countries whose real estate market development is of many similarities with China. Therefore, there experience can be provided as some references [3].

\subsection{The United States}

The type of American property tax is absolutely decentralized. Local governments have the legislative and executive powers to decide on the tax base and rate, which is in accordance with their political system. It is the variety of tax rate that make them adapt to different situations flexibility.

To sum up, the basic principle of the US property tax is "wide tax base, less tax rate". The tax rate is high on the holding cycle but it is relatively light for transferring parts. It varies from states to states according to different tax base. What China can learn from them most is that tax rate should be set differentially.

\subsection{Japan}

Japan began to conduct a comprehensive tax reform in 1950. According to the prevailing "Bishop proposal", Japanese established the basic framework of modern property tax which not only solved its government financial deficit problem, but also made tremendous contributions for the financing funds as well as the improvement of education and health care environment. 
Table 1 Comparisons of property tax between China and the US

\begin{tabular}{|c|c|c|}
\hline Taxpayer & $\begin{array}{c}\text { US } \\
\text { Only for the owner of the property, } \\
\text { including houses owners and renters, } \\
\text { not residential tenants. }\end{array}$ & $\begin{array}{c}\text { CHINA } \\
\text { Operational house property owners or users } \\
\text { of the inner cities, counties, towns and } \\
\text { mining areas. }\end{array}$ \\
\hline $\begin{array}{c}\text { Object of } \\
\text { taxation }\end{array}$ & $\begin{array}{c}\text { The object is residential house, using } \\
\text { the patterns of real estate and land. }\end{array}$ & $\begin{array}{c}\text { It is the operational house property, not } \\
\text { including real estates within the rural range. }\end{array}$ \\
\hline Tax rate & $\begin{array}{c}\text { Different regions and communities } \\
\text { have different tax rates. It may be } \\
\text { high as } 2.5 \% \text {, or low as } 0.5 \% .\end{array}$ & $\begin{array}{c}\text { The tax rate is } 1.2 \% \text { referred as deducting } \\
10 \% \text { of the original value of the property to } \\
\text { the residual value of 30\% while tax rate for } \\
\text { rental income is } 12 \% .\end{array}$ \\
\hline
\end{tabular}

Table 2 Comparisons of property tax between China and the Japan

\begin{tabular}{|c|c|c|}
\hline $\begin{array}{c}\text { Scope of } \\
\text { taxation }\end{array}$ & $\begin{array}{c}\text { The scope is broad, including the } \\
\text { owned houses, shops, factories, } \\
\text { warehouses and other appendage } \\
\text { groups which can increase the value } \\
\text { of properties. }\end{array}$ & $\begin{array}{c}\text { CHINA } \\
\text { The tax scope is too small, only in the city, } \\
\text { the county and a number of industrial and } \\
\text { mining areas. }\end{array}$ \\
\hline Focus & $\begin{array}{c}\text { It includes fixed property tax, city } \\
\text { planning tax and business income tax. } \\
\text { tax rate according to the time home } \\
\text { buyers hold to the ownership. }\end{array}$ & $\begin{array}{c}\text { The tax burden is relatively heavy in the } \\
\text { purchase real estate, the transfer of the tax } \\
\text { while it is too light in the real estate } \\
\text { holdings stage. }\end{array}$ \\
\hline
\end{tabular}

It is the truth in Japan that fairness should be taken into the consideration when assessing the tax rate. Under the standard rate of central government regulations and the maximum limit, the local governments have the right to float it within a reasonable range. So, China need take account of fairness and use the tax submitted to local education, health and infrastructure utilities.

\section{Adverse on Property Tax reform}

\subsection{Timely expansion of the tax base of property taxes.}

Although the tax range has extended to the taxation of property tax increment during the reform pilot today, it is still difficult to broaden the tax scale and it is supposed to include the existing or new houses. Nowadays, the socialist market economy of China has become stronger and the urban areas have been expanded, the areas that meet the conditions of the urban and rural real estate should be set as objects of taxation. But this setting cannot be applied across the country, due to the unbalanced development of the east and west of China [4]. We should give full considerations to the rural property taxpayer's actual capacity and propose a series of tax policies timely. Currently the pilot is only for non-business incremental housing, then it will be extended to non-operating stock of housing, more truly reflect the ability of the taxpayers' actual tax burden. 


\subsection{Build reasonable property assessment system to assess the value as the tax basis.}

Current tax is based on the original value of the property. Although it has many convenient places, it no longer meets today's society progress as China's economic development. Local governments should set up specialized rating agencies to set the assessment interval between three and five years. A set of appropriate valuation methodologies should be explored to adapt housing industry development in our country. Based on the valuation, the property tax can be calculated to better reflect the principle of fairness and also brings good benefits. It can also play the function of the automatic stabilizers using the assessment value since the assessed value will change and play a role in stabilizing the housing market, reducing additional residents to purchase real estates and promoting the healthy and stable development of property market.

\subsection{Implement the differential tax rates.}

The current real estate tax rate policy is unreasonable and should be improved, which means that local governments should be given power to make different tax rate under the premise of a nationwide unified tax system according to the actual situation. The government should do many researches to develop more suitable proportional tax rate, considering the value of local property taxpayers, the severity of the particular use of property tax and other issues. Property taxes should be implemented to differentiated progressive tax because of the sensitivity of different income groups. Property can be divided into different types according to office space and living space. Different types of housing should be based on to respectively determine the property tax rate. Due to China's vast areas and different levels of economic development in various places, local governments should determine property tax rates according to the size of the developmental needs of the country within the limited scope of national government.

\subsection{Strengthen the collection and management of property tax.}

On the one hand, the dynamic monitoring system of tax sources needs to be strengthened. It is fundamental to build up sources of tax revenue accounting and establish a ground tube combined with property tax revenue sources, premises linkage mechanisms and data management system. The software system updating the basic data should be included in the daily management of the property taxes to improve the dynamic monitoring [5].A bond that is from households registering, tax inspecting, data updating, tax assessing, tax reporting to performance evaluating should be founded to ensure the complement of tax system in property.

On the other hand, the collection and management of property tax reporting system needs to be enhanced. It should be included in the property tax levy collection and reporting quality assessment category and be supervised with early warning. It is vital to check the reasonableness and completeness of the property tax reporting to timely remind them and lead them into the correct direction. Government should apply different methods towards different situations. If the taxpayer pays less or even doesn't pay for the property tax, he is supposed to be fined and correct to the right direction. However, if the tax payer refuses to pay the tax or is even for intentional evasion, public punishment and enforcement measures should be taken in order to play the function of deterrence and shock.

\section{Conclusion}

The reform of property tax, as an integral part in deepening the fiscal and tax reform, has some positive influences in opening the financial sources of local government, reversing the serious financial dependence on land of local government, improving the existing revenue-sharing system and changing the existing weakness of property tax system [6]. Its immediate goal is to solve the shortage of local financial resources for local governments to provide with new stable and sustainable sources of revenue and to gradually replace land finance to achieve complete transformation.

In the implementation of property tax reform, we should take into the account of our special nature of our country, the enormity of the task and the long-term nature to establish a property tax reform plan in line with China's national conditions and correspond with Chinese characteristics. It should be set up step by step, implemented in different periods and performed steadily. 


\section{Reference:}

[1] Yuling Cao, The necessity, dilemma and countermeasures of China's current property tax reform, Urban planning and management, 2014,No.10, p. 140-141.

[2] Peng Zhan, The inequality between our residential property taxes and income, Dynamic Economics, 2015, No.7, p.14-24.

[3] Liming Dong, Honglei Pei, Property tax bases: the experience and implications of typical nations, The Studies on local finance, 2015,No.2, p.30-34.

[4] Wei Hua, Teng Gong, A research on the proposals of our property tax reform, Contemporary Economic Management, Vol. 37 (2015) No. 6, p. 82-85.

[5] Hongxia $\mathrm{Yu}$, The problems and coping strategies of our property tax reform, Finance and taxation, 2013, No.7, p.42-43.

[6] Fang Tian, The goal and path of the reform in property tax, Research on Financial and Economic Issues, 2015,No.5, p.110-116. 